\title{
Use of external nasal strip influences alveolar cell population of horses after exercise
}

[Uso de fita nasal influencia a população de células alveolares em equinos após exercício]

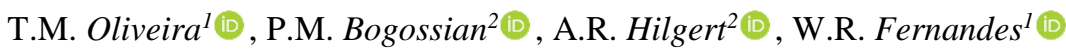 \\ ${ }^{1}$ Universidade de São Paulo, Faculdade de Medicina Veterinária e Zootecnia, São Paulo, SP, Brasil \\ ${ }^{2}$ Graduate, Universidade de São Paulo, Faculdade de Medicina Veterinária e Zootecnia, São Paulo, SP, Brasil
}

\begin{abstract}
The nasal strip is widely used in horses during exercise, but effects of using a nasal strip are controversial and little is known about its effect on horses undergoing endurance events. The aim of this study was to determine whether the use of nasal strips influences alveolar cell population assessed by bronchoalveolar lavage (BAL), tidal volume, and nasal airflow rate. Six Arabian horses were subjected to two low intensity tests on a treadmill, with and without application of a commercial external nasal strip. Tidal volumes and airflow rates were measured during the test; two hours after the test, BAL was performed to assess cytology of pulmonary secretions. The lavage fluid showed increased neutrophil count after exercise in animals with the nasal strip $(P<0.05)$. This suggests that turbulence of airflow through the nasal cavity may have diminished with nasal strip use, thus allowing larger particles to be deposited more distally in the respiratory system, inducing a more intense neutrophilic response. No differences in tidal volumes or airflow rates were observed between groups (with or without nasal strips) during the test $(P>0.05)$. The use of nasal strips seems to influence alveolar cell population during and after exercise in horses after low intensity exercise tests. Further studies are needed to verify whether alveolar cell population is related to poor exercise performance in horses.
\end{abstract}

Keywords: neutrophils, nasal strip, aerobic capacity

\section{RESUMO}

A fita nasal é amplamente utilizada em equinos durante o exercício, porém seus resultados são controversos e pouco conhecidos em animais que disputam provas de resistência. O objetivo deste trabalho foi verificar se o uso da fita nasal influencia a população de células alveolares por meio de lavado broncoalveolar, volume corrente e fluxo de ar nasal. Foram utilizados seis equinos da raça Árabe, que realizaram dois testes de longa duração em esteira, sendo um teste com a fita e outro sem a fita nasal. Fluxo e volume respiratório foram mensurados durante o teste; duas horas após o término do exercício, foi realizado lavado broncoalveolar para realização de citologia da secreção pulmonar. Foi verificada maior porcentagem de neutrófilos após o exercício nos animais que se exercitaram com a fita nasal $(P<0,05)$, indicando que o turbilhonamento na passagem do ar através da cavidade nasal pode ter diminuído, permitindo que partículas maiores se depositassem em porções mais distais do sistema respiratório, induzindo uma resposta neutrofilica mais intensa. Não houve diferenças entre os parâmetros ventilatórios analisados entre os animais quando correram com ou sem a fita nasal $(P>0,05)$. O uso da fita nasal parece influenciar alguns parâmetros, durante e após o exercício, em animais que realizam provas de longa duração. Outros estudos devem ser realizados para verificar se essa influência pode melhorar o desempenho desses animais em exercícios predominantemente aeróbicos.

Palavras-chave: neutrófilos, fita nasal, capacidade aeróbica

\section{INTRODUCTION}

Respiratory physiology is an active, challenging research area in equine sports science, as there is increasing evidence that maximal oxygen uptake is one of the most important factors limiting exercise performance in medium to long distance rides (Evans, 2007; Marlin, 2015). Horses are

Corresponding author: tiagooliveira@usp.br

Submitted: February 4, 2021. Accepted: May 24, 2021. 
often hypoxic at high workloads (average $\mathrm{PO}_{2}=$ $70 \mathrm{mmHg}$ ) (Bayly et al., 1989), due to several inherent characteristics related to $\mathrm{O}_{2}$ diffusion. There are many specific characteristics in horses that contribute to this phenomenon, such as very high blood flow in the lungs (Davie et al., 2017); exclusively nasal breathing; and respiratorylocomotor coupling (Art et al., 1990b; Butler et al., 1993).

There are a few studies that have addressed the precise role of upper airway structures on airflow during exercise (Janicek and Ketzner, 2008). The equine upper airway is a high-resistance, lowcapacity airway passage, being responsible for approximately $80 \%$ of the total airway resistance during exercise (Art et al., 1990a). Increased airway resistance is probably an additional factor that limits oxygen uptake and increases transmural pressure, as it may increase breathing effort, especially during long rides (Ducharme et al., 1999).

It has been proposed that the nasal passage is likely to play an important role in airflow restriction, especially in horses. This is because the unsupported area of the nose rostral to the nasoincisive notch may collapse during inspiration following intense exercise, resulting in increased tracheal inspiratory pressures (Holcombe et al., 2002). Poole et al. (2000) stated that the use of external nasal support reduces red blood cell count in the BAL fluid after intense exercise in Thoroughbred horses, suggesting that it may prevent exercise induced pulmonary hemorrhage (Poole et al., 2000). However, this was questioned by Geor et al. (2001), who found no additional red blood cell reduction in the BAL fluid following exercise after application of nasal strip in horses previously treated with furosemide (Geor et al., 2001).

In contrast, there is evidence that nasal strips reduce the metabolic cost of supra-maximal at $120 \%$ maximum oxygen consumption $\left(\dot{\mathrm{V}}_{2} \max \right)$ (Geor et al., 2001), and progressive exercise (Poole et al., 2000). It was observed that horses were able to reach lower values of maximal oxygen uptake following the use of external nasal support, suggesting that the nasal strip acts by reducing airway resistance during strenuous exercise (Poole et al., 2000). An additional hypothesis underlying metabolic cost is related to VO2 kinetics. External nasal support may increase oxygen consumption during the early submaximal phase of exercise and decrease energy released through anaerobic pathways, as described in studies that evaluate the influence of previous exercise on $\dot{\mathrm{VO}} 2$ kinetics (McCutcheon et al., 1999)

The influence of the external nasal strip on respiratory work and alveolar cell population during prolonged, low intensity exercise remains unknown. It was hypothesized that the external nasal strip could alter alveolar cell population and parameters like airflow and tidal volume during and after exercise. Therefore, the aim of this study was to verify whether the use of the nasal strip alters respiratory parameters during and alveolar cell population after a single exercise session of long duration.

\section{MATERIAL AND METHODS}

Six untrained Arabian horses (two geldings and four mares), weighing 350 to $382 \mathrm{~kg}$, and average age of $9 \pm 1$ years were evaluated. All horses were housed in standard boxes (two horses per box), on sawdust, regularly fed with coast-cross hay, commercial concentrate $(2 \mathrm{~kg})$ twice a day, and the horses were given free access to water.

The preparation of the animals started three months before the beginning of the tests. The hooves were trimmed and inspected every 20 days because the horses did not use horseshoes. The horses were dewormed with ivermectin and praziquantel.

In the beginning of the adaptation the horses were taken individually to the treadmill room. Inside, they were accustomed to the acoustic of the room and members of the team. Upon this adaptation period, the horses were submitted to walking and trotting on the treadmill for 10 to 15 minutes per day. At the end of the exercise, the mask was positioned covering the oral cavity and nostrils until they seemed comfortable with the equipment.

A randomized horizontal crossover study was designed to test the effect of the commercial nasal strip on alveolar cell population in exercising horses and the study was approved by the Ethic Committee on Animal Use of the School of Veterinary Medicine and Animal Science of São Paulo University (CEUA/FMVZ) protocol number $n^{0}$ 1155130215. Each horse performed 
two standardized exercise tests (SET) on a treadmill with and without a nasal strip, with a gap of seven days in between. BAL was performed seven days before the first SET (control) and 120 minutes after each SET, carried out with and without the nasal strip.

Prior to the beginning of the experiment, a clinical exam was performed that covered: heart rate, respiratory auscultation and rate, rectal temperature, mucous membrane inspection and lameness exam. All horses were submitted to hematological evaluation. The results of these exams were inside the normal parameters for horses, and these were the inclusion factors for this experiment. No coughing or excessive respiratory effort were noted.

Three horses were submitted for the first treadmill test with the nasal strip and the other three were submitted for the first test without the nasal strip. Then, we swapped the use of the nasal strip between the horses in such a way that horses previously with the nasal strip now did not use it, and vice-versa. The interval between the tests was seven days. BAL was performed seven days before the first SET (control) and 120 minutes after each SET, carried out with and without the nasal strip.

Horses were sedated with xylazine $0.5 \mathrm{mg} / \mathrm{kg}$ intravenously and physically restrained with twitch. A silicon catheter (Bivona ${ }^{\mathrm{TM}}$ ) measuring three meters was inserted into the ventral meatus of the right nostril. Local anesthetic (lidocaine $0.5 \% ; 20 \mathrm{~mL}$ ) was used to prevent bronchospasm during the procedure. After positioning the probe, $40 \mathrm{~mL}$ of saline (NaCL $0.9 \%$ ) was infused, and repeatedly aspirated until at least $20 \mathrm{~mL}$ of bronchoalveolar content was obtained. All samples were stored in Falcon TM tubes and centrifuged ( $3500 \mathrm{rpm} ; 10 \mathrm{~min}$ ). The pellet was suspended for use on microscopy laminae and stained in duplicate by the Rosenfeld method (Rosenfeld, 1947).

All laminae were evaluated through optical microscopy immersion (800x), by a single observer who was blinded to the type of the sample analyzed. The first three hundred cells counted were classified as epithelial cells, macrophages, neutrophils, eosinophils, multinucleated cells and foamy macrophages. The proportion of each cell type was presented as percentage and absolute values.

Airflow, tidal volume and respiratory frequency were measured using a collection system with a Quadflow mask and pneumotachometer (Curtis et al., 2005). The calibration was performed by means of the software from Medgraphics Breezesuite with a 6-liter syringe and the four sensors positioned in series, to use in parallel later upon in the facemask. The temperature, humidity and pressure within the room were recorded at the moment of calibration and trials. The mask covered the oral cavity and nostrils of the horses and allowed full dilation of the nostrils. Basal values were obtained at rest.

During the low intensity test, samples were collected at the end of each moment with the horse on the treadmill. The treadmill was paused for 30 seconds every 15 minutes for measurements to be obtained, and exercise restarted at the next moment. Four samples were obtained during the test and one sample five minutes after the end of the test. In addition, the mask is sealed by a latex edge in touch with the horse's skin, allowing airflow only through the sensors. Data were obtained and recorded using the WFATester ${ }^{\circ}$ software. Airflow and volume graphs were generated, in addition to numerical data.

All SETs were performed between 2:00 and 5:00 p.m. within a period of ten days with a minimal interval of seven days. Test protocol consisted of sixty minutes of exercise at a fixed speed of 3.2 $\mathrm{m} / \mathrm{s}$ without inclination.

The region located $3.8 \mathrm{~cm}$ above both nostrils was prepared with water and neutral soap and the nasal strip was placed through a commercial guide.

Descriptive statistics (mean and standard deviation) were calculated for BAL cytology. One-way analysis of variance (ANOVA) was used. Differences within each treatment group (pre-and post-nasal strip; pre-and post-control) were obtained using the Wilcoxon test. Means were compared using the Tukey's test. Significance was considered at $P \leq 0.05$. Data are shown as mean \pm standard error of mean (SEM). Data in graphs are presented as the mean \pm SEM (R: R ${ }^{\mathrm{TM}}$ version 2.15.1 (2012-06-22). 


\section{RESULTS}

Samples of BAL were obtained from six horses, at rest and after exercise, with and without the nasal strip. Macroscopically, all samples showed a foamy surfactant layer, with a slightly turbid and whitish appearance. Mean values with standard deviation of alveolar cell population in the BAL fluid are expressed in Table 1.

Table 1. Percentual mean and standard deviation (SD) of the counts of epithelial cells, eosinophils, neutrophils, lymphocytes, macrophages, multinucleated cells, and foamy macrophages obtained at rest, and after SET with and without the nasal strip (NS)

\begin{tabular}{lcccccc}
\hline \multicolumn{1}{c}{ Cell type } & \multicolumn{2}{c}{ Rest } & \multicolumn{2}{c}{ With NS } & \multicolumn{2}{c}{ Without NS } \\
\cline { 2 - 7 } & Mean & SD & Mean & SD & Mean & SD \\
\hline Epithelial cells & 2.94 & 5.95 & 0.78 & 0.50 & 15.17 & 20.03 \\
Eosinophils & 1.06 & 2.43 & 0.61 & 0.85 & 0.06 & 0.14 \\
Neutrophils & 20.61 & 21.42 & $36.28^{*}$ & 14.50 & 20.33 & 16.59 \\
Lymphocytes & 1.39 & 1.67 & 1.06 & 1.65 & 0.56 & 0.81 \\
Macrophages & 72.00 & 19.80 & 60.72 & 14.25 & 62.83 & 22.49 \\
Multinucleated cells & $2.00^{*}$ & 1.21 & 0.50 & 0.59 & 0.67 & 0.87 \\
Foamy macrophages & 0.00 & 0.00 & 0.00 & 0.00 & 0.28 & 0.53 \\
\hline
\end{tabular}

A significant difference in multinucleated cells was observed after exercise, with and without the nasal strip $(P<0.05)$. Nasal strip use resulted in increased alveolar recruitment of neutrophils. The neutrophil count in the BAL fluid was $43.96 \%$ higher after exercise with the nasal strip compared to exercise without the nasal strip $(P<0.01)$. (Fig. 1).

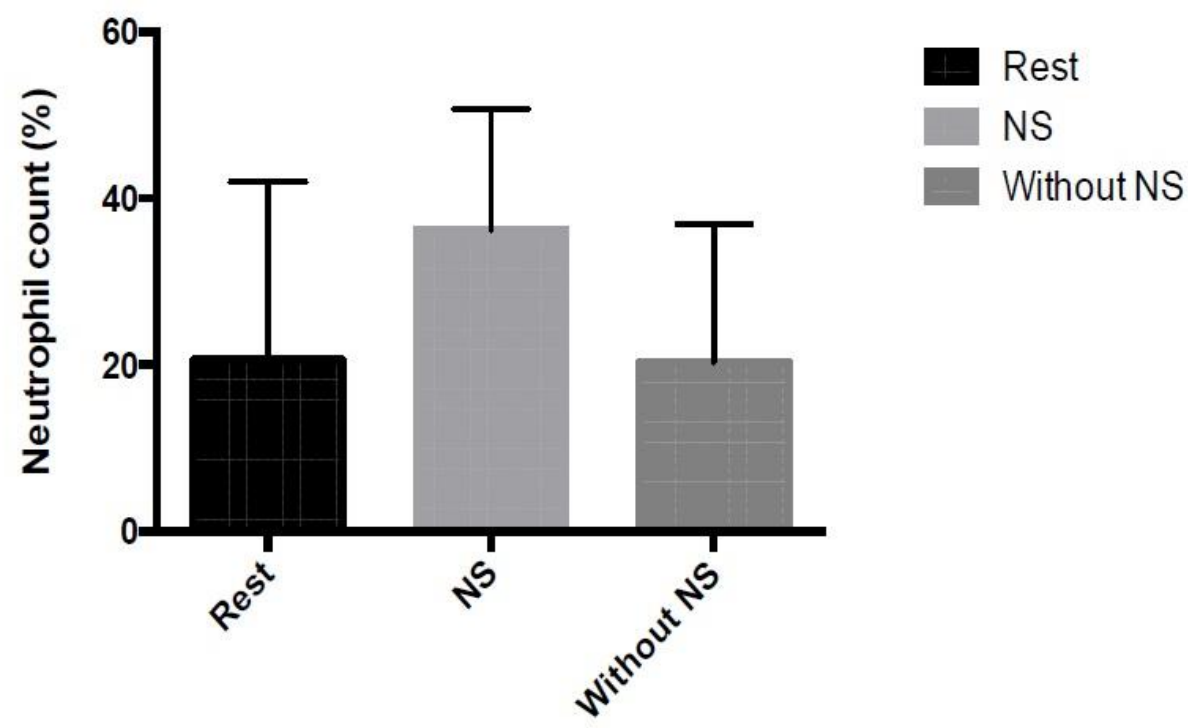

Figure 1. Comparison of neutrophil count at rest and after prolonged exercise with and without the nasal strip (NS) $(\mathrm{n}=6)$

No difference in count was observed in epithelial cells, eosinophils, lymphocytes, macrophages and macrophages foamy count at rest, and following exercise, with or without the nasal strip. Respiratory frequency, airflow and tidal volumes also remained unchanged. (Fig. 2). The collection method with a Quadflow mask and pneumotachometer was efficient and made it possible to obtain samples at all times. 
Respiratory Rate

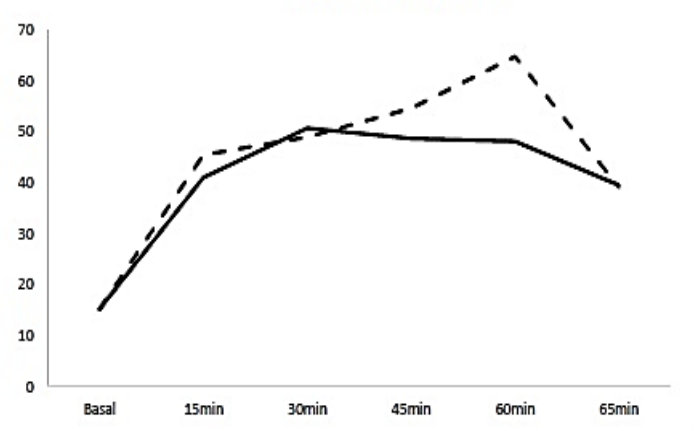

Tidal Volume

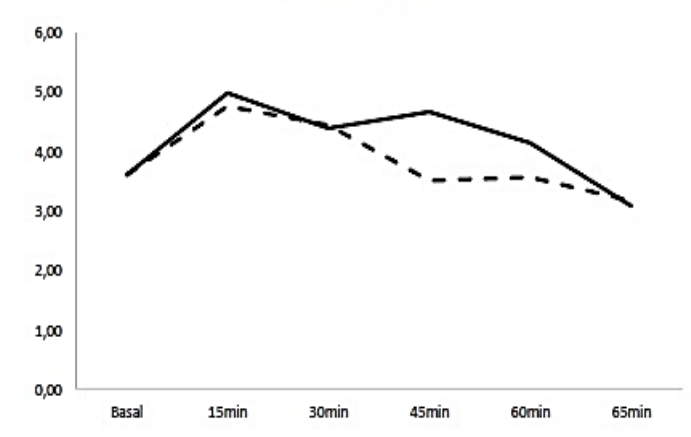

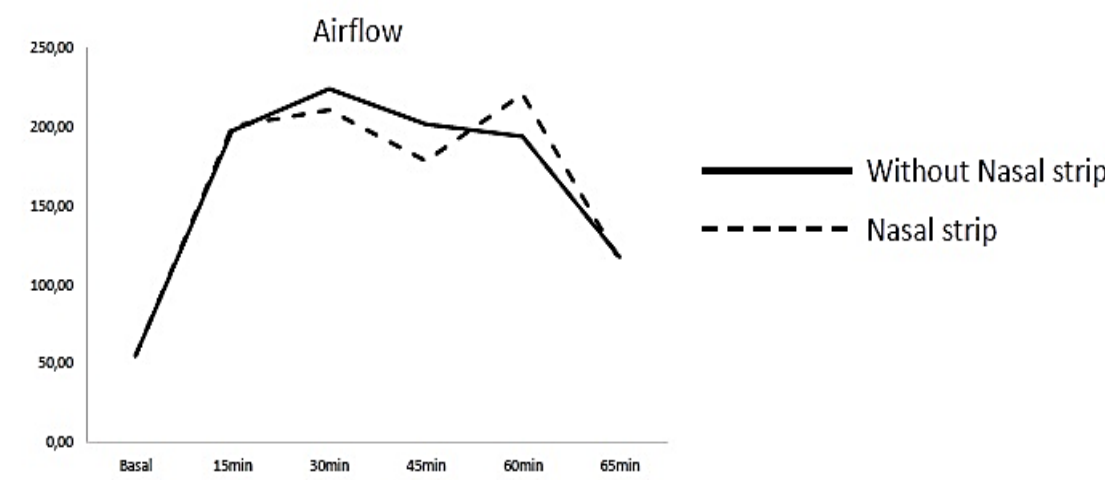

Figure 2. Respiratory Rate (bpm), tidal volume (Liters) and airflow Liters/minute) during the six collect moments with and without nasal strip (NS) (n=6)

\section{DISCUSSION}

The role of external nasal support on airway resistance, exercise-induced pulmonary hemorrhage and maximal oxygen uptake has been previously described (Goetz et al., 2001; Holcombe et al., 2002). However, to the best of our knowledge, the relationship between nasal strip-related changes on nostril morphology and alveolar recruitment during prolonged exercise has not been yet described. The results of this study indicate that the alveolar population of neutrophils is remarkably influenced by increased external nasal support during exercise. Despite the lack of data regarding the effect of the nasal strip on nostril function, we speculate that changes in airflow patterns at the opening of the nasal passage might account for changes in cell population detected on BAL. Furthermore, dynamic collapse of the nostril during exercise seems to influence air filtration in exercising horses, due to the natural turbulence at the rostral end of the air passage. Nasal aerodynamic changes due to the nasal strip may allow the inhalation and deposition of larger particles more distally in the bronchi, resulting in a local immunological response.
During the tests we noted more stability in the region of the rostral skin to the nasoincisive notch, showing that the nasal strip provides a greater stabilization of this region. For high intensity exercises, this stabilization can contribute to the increase in tidal volume, a parameter that is responsible for the increase in minute volume in this type of activity. In addition, during intense exercise there is a possibility of the nostrils' lateral wall collapsing, which can be prevented with the use of the nasal tape. However, the movement of these structures in low intensity exercises does not seem to cause as much damage to the animal's performance as in high intensity ones.

Our results are in contrast to a previous study by Valdez et al. (2004) who failed to observe any difference in alveolar neutrophil population in Thoroughbred horses wearing nasal dilatator during racetrack exercise. Despite the lack of statistical difference, they reported higher neutrophil counts during trials wearing nasal dilatators $(6.9 \pm 2 \%)$ compared to controls (5.6 $\pm 1.6 \%)$ (Valdez et al., 2004). 
In the present study, the average neutrophil count in BAL at rest was $20.61 \%$, which is higher than expected for healthy horses according to previous data (1.5 - 22\%) (Art et al., 1990b). However, clinical and hematological evaluation did not reveal signs of infectious disease. We speculate that infused volume, exercise protocol and collection time might have influenced the neutrophil count. The volume of $0.9 \%$ saline solution infused $(40 \mathrm{~mL})$ during BAL may contribute to higher neutrophil counts. Sweeney et al. (1994) suggest that higher neutrophil values may be observed with infused volumes around 50 $\mathrm{mL}$, because of incomplete alveolar filling (Sweeney et al., 1994). As a higher number of neutrophils are seen in more proximal bronchi, selective lavage of this area might present a higher proportion of neutrophils (Valdez et al., 2004). However, we inserted the catheter as deep as possible; hence, we consider bronchial lavage unlikely. Mair et al. (1987) also observed higher neutrophil values in the BAL fluid compared with other techniques for sampling pulmonary secretions (Mair et al., 1987).

Another factor that may increase neutrophils count is the collection time after standardized exercise tests. BAL was carried out 120 minutes after SET, such as to the study by Clark et al. (1995), who found a higher neutrophil count 45 minutes after exercise in trained horses (Clark et al., 1995). Another experiment evaluate twenty seven healthy Quarter horses thirty minutes after completing 3-Barrel Racing Exercise and they found an average $23 \%$ of neutrophils and $44 \%$ of epithelial cells on traqueal wash (Michelotto et al., 2007). In our experiment, BAL was possibly performed on the right lung, as the catheter usually passes to the caudodorsal portion of the right lung due to the normal anatomical orientation of the tracheobronchial tree (Hodgson and Hodgson, 2007). Depecker et al. (2014) found that the a higher number of neutrophils is seen on the right side, due to higher exposure to allergens and microorganisms (Depecker et al., 2014), although some authors claim that the side of lavage does not influence leukocyte counts (McGorum et al., 1993; Meyer et al., 1998). The higher neutrophil count may also be related to the fact that our horses were not subjected to the stress caused by physical training and previous transport for performing SET. It has been suggested that the continuous exercise training can reduce the leukocyte levels in the BAL fluid due to the increased release of plasma cortisol induced by physical stress, which may inhibit leukocyte migration into the airways (Clark et al., 1995). Suppression of neutrophil response, and decreased total leucocyte count were also reported after stress caused by transportation (TraubDargatz et al., 1988).

Couëtil and Denicola (1999) found higher percentages of lymphocytes in BAL fluid 24 hours after high intensity exercise (Couëtil and Denicola, 1999). The authors concluded that this would be secondary to the greater mobilization of cells from lung tissue or an influx of inflammatory cells into the lungs. However, Valdez et al. (2004) found significant differences in the relative and absolute numbers of lymphocytes, with higher counts in horses that exercised without the nasal strip (Valdez et al., 2004). These data differ from ours, probably because the interval between SET and BAL was different between studies. Two hours after SET, we observed a higher neutrophil count. We observed a lower lymphocyte count post SET probably because of the higher proportion of neutrophils and epithelial cells found in our study. Serial collection at 2, 12, and 24 hours for a period of seven days is required to determine whether an immune response progresses with time, and for reconstitution of pulmonary secretions (Clark et al., 1995; Fernandes et al., 2000).

The epithelial cell count may be indicative of tissue lines and was close to zero in 14 of $18 \mathrm{BAL}$ volume instilled samples. However, in four samples from different horses (three samples without the nasal strip and one baseline sample) epithelial cell values exceeded $10 \%$. Epithelial cells may be very few or absent in BAL fluid; this suggests that samples are from alveolar cell population and that the collection procedure did not result in trauma to the airway mucosa (Fernandes et al., 2000). The higher number of epithelial cells in these four horses may have been influenced by the volume of collection, besides the higher number of neutrophils present in the bronchi. Mair et al. (1987) observed epithelial cell counts of $32.5 \%$ in bronchial washings and $14.3 \%$ in BAL fluid (Mair et al., 1987). They attributed this to contamination of the sample as the catheter passed through the proximal respiratory system, a region with large numbers of epithelial cells due to constant epithelial renewal. CouroucéMalblanc et al. (2002) also observed an increase 
of epithelial cells in low performance horses (Couroucé-Malblanc et al., 2002). However, these authors attributed their findings to associated viral infections leading to epithelial erosion, although there were no other signs of illness. We hypothesize that our sample counts were influenced by the volume used for collection and passage of the catheter through the proximal airways.

The number of macrophages after SET with the nasal strip was not different from controls. This is as reported previously (Valdez et al., 2004), when BAL was carried out from 12 to 18 hours after physical activity. Macrophages increased activity in a second time due to the stimulus in the lung tissue. However, increased proportions of these cells are difficult to detect as macrophages are resident cells in the lung environment (Hodgson and Hodgson, 2007). Therefore, it was expected that BAL performed two hours after SET showed no difference in macrophage count between groups. The number of foamy macrophages were very few and did not allow statistical analysis, which was also expected for healthy animals that participated in the study.

Other cells showed close to zero counts in the BAL fluid as expected in healthy animals. The number of eosinophils in the three groups was consistent with previously reported values (Fernandes et al., 2000; Hughes et al., 2003). As expected, this parameter was not influenced by exercise and use of the nasal strip. Hughes et al. (2003) found that the collection method (tracheal aspirate or BAL) also does not influence the presence of these cells, and that the mobilization of these cells to the lungs is more related to allergic processes and pneumonia caused by parasites (Hughes et al., 2003). There was a statistically significant difference in multinucleated cells between the basal and post exercise (with and without the nasal strip) samples, with a significantly higher number in the basal samples. The number of multinucleated cells are commonly found to be low in both tracheal washings and BAL fluid in horses with no evidence of inflammatory disease; they are found to be higher in chronic lung inflammation (Hodgson and Hodgson, 2007). However, these cells can be found in horses with no evidence of significant pulmonary inflammatory disease (Beech, 1991).

\section{CONCLUSION}

Use of nasal strips during prolonged low intensity exercise influences alveolar cell population and does not influence airflow, volume and respiratory rate in Arabian horses. The proportion of neutrophils increases in response to SET with the nasal strip.

\section{REFERENCES}

ART, T.; ANDERSON, L.; WOAKES, A.J.; ROBERTS, C. et al. Mechanics of breathing during strenuous exercise in thoroughbred horses. Respir. Physiol., v.82, p.279-294, 1990a.

ART, T.; DESMECHT, D.; AMORY, H.; LEKEUX, P. Synchronization of Locomotion and Respiration in Trotting Ponies. J. Vet. Med. A, v.37, p.95-103, 1990 b.

BAYLY, W.M.; HODGSON, D.R.; SCHULZ, D.A. et al. Exercise-induced hypercapnia in the horse. J. Appl. Physiol., v.67, p.1958-1966, 1989.

BEECH, J. Tracheobronchial aspirates. In: BEECH, J. (Ed.). Equine respiratory disorders. Philadelphia: Lea \& Febiger, 1991. p.41-53.

BUTLER, P.J.; WOAKES, A.J.; ANDERSON, L.S. et al. Stride length and respiratory tidal volume in exercising thoroughbred horses. Respir. Physiol., v.93, p.51-56, 1993.

CLARK, C.; LESTER, G.; VETRO, T.; RICE, B. Bronchoalveolar lavage in horses: effect of exercise and repeated sampling on cytology. Aust. Vet. J., v.72, p.249-252, 1995.

COUËTIL, L.L.; DENICOLA, D.B.; Blood gas, plasma lactate and bronchoalveolar lavage cytology analyses in racehorses with respiratory disease. Equine Vet. J., v.30, Suppl., p.77-82, 1999.

COUROUCÉ-MALBLANC, A.; PRONOST, S.; FORTIER, G. et al. Physiological measurements and upper and lower respiratory tract evaluation in French Standardbred Trotters during a standardised exercise test on the treadmill. Equine Vet. J., v.34, Suppl. p.402407, 2002

CURTIS, R.A.; KUSANO, K.; EVANS, D.L. et al. Reliability of cardiorespiratory measurements with a new ergospirometer during intense treadmill exercise in Thoroughbred horses. Vet. J., v.169, p.223-231, 2005.

DAVIE, A.J.; WEN, L.; CUST, A.R.E. et al. The effects of moderate intensity training in a hypoxic environment on transcriptional responses in Thoroughbred horses. Biol. Open, v.6, p.1035-1040, 2017. 
DEPECKER, M.; RICHARD, E.A.; PITEL, P.H. et al. Bronchoalveolar lavage fluid in Standardbred racehorses: Influence of unilateral/bilateral profiles and cut-off values on lower airway disease diagnosis. Vet. J., v.199, p.150-156, 2014.

DUCHARME, N.G.; HACKETT, R.P.; GLEED, R.D. et al. Pulmonary capillary pressure in horses undergoing alteration of pleural pressure by imposition of various upper airway resistive loads. Equine Vet. J., v.30, Suppl., p.27-33, 1999.

EVANS, D.L. Physiology of equine performance and associated tests of function. Equine Vet. J., v.39, p.373383, 2007.

FERNANDES, W.R.; MORI, E.; SANCHES, A Avaliação citológica de lavados traqueobrônquico e broncoalveolar em cavalos clinicamente sadios pelo método de coloração de Rosenfeld. Arq. Bras. Med. Vet. Zootec., v.52, p.604-609, 2000.

GEOR, R.J.; OMMUNDSON, L.; FENTON, G.; PAGAN, J.D. Effects of an external nasal strip and furosemide on pulmonary haemorrhage in Thoroughbreds following high-intensity exercise. Equine Vet. J., v.33, p.577-584, 2001.

GOETZ, T.E.; MANOHAR, M.; HASSAN, A.S.; BAKER, G.J. Nasal strips do not affect pulmonary gas exchange, anaerobic metabolism, or EIPH in exercising Thoroughbreds. J. Appl. Physiol., v.90, p.2378-2385, 2001.

HODGSON, J.L.; HODGSON, D.R. Collection and analysis of respiratory tract samples. In: MCGORUM, B.C.; DIXON, P.M.; ROBINSON, N.E.; SCHUMACHER, J. (Eds.). Equine respiratory medicine and surgery. Philadelphia: Saunders, 2007. p.119-150.

HOLCOMBE, S.J.; BERNEY, C.; CORNELISSE, C.J et al. Effect of commercially available nasal strips on airway resistance in exercising horses. Am. J. Vet. Res., v.63, p.1101-1105, 2002.

HUGHES, K.J.; MALIKIDES, N.; HODGSON, D.R.; HODGSON, J.L. Comparison of tracheal aspirates and bronchoalveolar lavage in race-horses 1 . Evaluation of cytological stains and the percentage of mast cells and eosinophils. Aust. Vet. J., v.81, p.681-684, 2003.

JANICEK, J.C.; KETZNER, K.M. Airflow mechanics, upper respiratory diagnostics, and performancelimiting pharyngeal disorders. Comp. Equine, v.3, p.366-380, 2008 .
MAIR, T.S.; STOKES, C.R.; BOURNE, F.J.. Cellular content of secretions obtained by lavage from different levels of the equine respiratory tract. Equine Vet. J., v.19, p.458-62, 1987.

MARLIN, D. Has the golden age of equine exercise physiology passed and if so, have we answered all the big questions? J. Equine Vet. Sci., v.35, p.354-360, 2015

MCCUTCHEON, L.J.; GEOR, R.J.; HINCHCLIFF, K.W. Effects of prior exercise on muscle metabolism during sprint exercise in horses. J. Appl. Physiol. (1985), v.87, p.1914-1922, 1999.

MCGORUM, B.C.; DIXON, P.M.; HALLIWELL, R.E.; IRVING, P. Comparison of cellular and molecular components of bronchoalveolar lavage fluid harvested from different segments of the equine lung. Res. Vet. Sci., v.55, p.57-59, 1993.

MEYER, T.S.; FEDDE, M.R.; GAUGHAN, E.M. et al. Quantification of exercise-induced pulmonary haemorrhage with bronchoalveolar lavage. Equine Vet. J., v.30, p.284-288, 1998 .

MICHELOTTO, P.V.; BIAVA, J.S.; GONÇALVES, R.C. et al. Aspirado traqueal de cavalos clinicamente sadios da raça quarto de milha após prova de três tambores. Arch. Vet. Sci., v.12, p.1-7, 2007.

POOLE, D.C.; KINDIG, C.A.; FENTON, G. et al. Effects of external nasal support on pulmonary gas exchange and EIPH in the horse. J. Equine Vet. Sci., v.20, p.579-585, 2000.

ROSENFELD, G. Corante pancrômico para hematologia e citologia clínica: nova combinação dos componentes do May-Grünwald e do Giemsa num só corante de emprego rápido. Mém. Inst. Butantan, v.20, p.329-334, 1947.

SWEENEY, C.R.; ROSSIER, Y.; ZIEMER, E.L.; LINDBORG, S.R. Effect of prior lavage on bronchoalveolar lavage fluid cell population of lavaged and unlavaged lung segments in horses. Am. J. Vet. Res., v.55, p.1501-1504, 1994

TRAUB-DARGATZ, J.L.; MCKINNON, A.O.; BRUYNINCKX, W.J. et al. Effect of transportation stress on bronchoalveolar lavage fluid analysis in female horses. Am. J. Vet. Res., v.49, p.1026-1029, 1988.

VALDEZ, S.C.; JORGE NIETO, E.; SPIER, S.J.; OWENS, S.D. et al. Effect of an external nasal dilator strip on cytologic characteristics of bronchoalveolar lavage fluid in Thoroughbred racehorses. J. Am. Vet. Med. Assoc., v.224, p.558-61, 2004. 